\title{
Muslims in Copenhagen: Social Cohesion or a Parallel Society? Results from an Empirical Survey 2008-09
}

\author{
Mustafa Hussain
}

\begin{abstract}
The Nфrrebro sub-district of Copenhagen, where $14 \%$ of the population belong to ethnic minorities, mainly Muslim, has stood on the Danish media's agenda for many years as a problem-ridden area, developing into a parallel society with ethnic ghettos, crime and deviancy among the second generation and lack of social cohesion and integration. This article introduces results from the survey 'At Home in Europe: Muslims in the European Cities' commissioned by the Open Society Institute, which examines the current policy and patterns of Muslim integration in eleven municipal districts of the seven metropolises of the EU countries. It argues that when measured across a range of parameters to ascertain the social, cultural and economic integration of the Muslim minorities, the empirical data and the documentary evidence gathered from, and about, the sub-district (2008-9) contradict the political claims and the media rhetoric of a parallel society.
\end{abstract}

This article reports a study that set out to understand the everyday experiences of ordinary Muslims living in the Inner Nørrebro sub-district of Copenhagen, with a particular focus on the impact and perception of public policies aimed at improving integration and social inclusion. Integration here is understood as a two-way process that requires engagements by individuals as well as opportunities for participation.

Existing academic research on Muslims and Islam in Denmark and in the rest of the European Union has as its main focus Muslim integration at a national level, covering 
such topics as encounters between Muslim minorities and national institutions (e.g. schools, legal structures, and hospitals), youth and radicalization, international terrorism and extremist groups, Muslim families and gender equality. Besides this and some research on theological approaches to the main tenets of Islam, there are also many ethnographic studies of Muslim culture(s), sectarian divides among Muslims, and historical accounts of strained relationships between the West and the Islamic world. Meanwhile, the aftermath of 9/11 has not only seen a renewed interest in the Muslim presence in Europe, but also the rise of far-right political movements across the Western world, against multiculturalism, Muslims and Islam. The 'Muslim question' has also stood high on the mainstream political agenda.

It is interesting to note, however, that even today many students and scholars involved in research on Muslim communities still end up collecting data from the holy scriptures of Islam, by frequenting mosques to interview clergy and political Islamists, or by monitoring their ideological propaganda - just as is the case with the mainstream media. Such inquiries paint an abstract, decontextualized and generalized image of ordinary Muslims and their everyday life. These generalized images often reproduce an us-them dichotomy on the dimensions of cultural norms, custom, and values. This sociological study, in contrast, embarked on exploring Muslim integration by highlighting the views and concerns of the average Muslim in two distinct aspects. First, how the average Muslim experiences day-to-day life through encounters with the local non-Muslim population, and perceptions of local welfare policies and practices of governmental institutions and-hence-what concerns are expressed about such interactions with the surrounding society. And second, how having a Muslim identity impacts on the perception of belonging to the city, and what prevents successful social integration. By bracketing the doctrinal divides between Islam and Christianity and between traditional religiosity and modern secularism, the survey provides a first-hand account of what Muslims themselves think and say regarding their daily lives and integration.

For the analysis of integration trends, the main parameters that are hypothesized to be crucial for social integration are education, employment, health, and civic and political 
participation. Measurement of these is supplemented with informal contacts and communication between the Muslim and non-Muslim population in the residential areas explored in the survey.

The survey was conducted during 2008 in the Inner Nørrebro sub-district of Copenhagen, which has an ethnic minority population of more than $14.6 \%$ of the district's total number of residents, which was 71,330 in January 2007, according to the municipal office of statistics. The overwhelming majority of the minority population in Nørrebro is believed to be of Muslim background.

\section{Methodology}

The survey was based on a common research design for all the eleven EU cities studied in the 'At Home in Europe' project of the Open Society Foundation, a think-tank supported by George Soros' Open Society Institute (OSI). This research was thus based on a uniform questionnaire survey conducted amongst 100 Muslim and 100 nonMuslim residents of the Inner Nørrebro sub-district, lasting on average one and a half to two hours. Six focus groups with an average of eight to ten Muslim participants, different from those who took part in the questionnaires, were also held in Nørrebro with self-identifying Muslims. In addition, eight in-depth qualitative interviews were held with local officials, members of non-government organizations and experts engaged on integration issues in Copenhagen and the country at large after the preliminary analyses of the survey data.

The sample frame for the quantitative data was designed to target the maximum representation of different ethno-national communities of Muslims as well as nonMuslims and was sub-sampled on the further dimensions of age and gender. In the category of the self-defined non-Muslims, $78 \%$ are native Danes and the rest are foreign nationals from various countries of Asia, Europe, America and Africa. 
The six focus groups among the Muslims, with an average of eight participants, both males and females, were held to elicit debate on the main topics of education and employment, health and welfare services, policing and civil and political participation.

\section{Perception of Muslims at national level}

A good deal of national and international research and inquiries suggest that attitudes in Denmark towards ethnic minorities have deteriorated since the late 1980s. Both the media discourse and the anti-immigrant rhetoric in parliament have become harsher towards Muslims in particular. Studies point to a change of direction in perceptions, attitudes and institutional behaviour, namely legislation about migration and integration, representation and portrayal in the mainstream media, political rhetoric about Islam and Muslims, or their depiction in the popular culture, such as television fiction, film and drama. Muslims are conceived as a culturally homogeneous group of 'foreigners' and in a binary opposition to all that is Danish. Several studies have focused on the role of the media in the reproduction of exclusionary discourse and practice (Hussain et al., 1997; Hervik et al., 1999; Hussain, 2000; Madsen, 2000; Hervik, 2003; Andreassen, 2005).

A recent EU-wide discrimination survey by the European Agency for Fundamental Rights (FRA) has explored perceptions of discrimination amongst two Muslim groups in Denmark, the Somalis and the Turks. It found that $61 \%$ of Somalis and $58 \%$ of Turks believed that discrimination based on ethnic or immigrant origin was widespread in the country (EU-MIDIS, 2009:6). A 2008 survey assessing discrimination based on religious identity in the EU countries revealed that an average of $42 \%$ of respondents were of the opinion that discrimination due to one's faith or religion was widespread in the EU countries. However, for Denmark the figure was not only significantly higher than the EU average, but it was also the highest among all the 27 countries, at $62 \%$ (Eurobarometer, 2008).

An analysis comparing the political rhetoric and perception of the Muslims in parliamentary debates between 1967 and 2005 with perception of Russian Jewish immigrants of the early twentieth century (1903-1945) concludes that the Muslims are 
talked about in the same way, as a threat to Danish values and culture, as Jews were talked and debated about in the Danish parliament in the pre-war period (Jacobson 2009).

An international Gallop poll conducted in 27 Muslim and Western countries commissioned by World Economic Forum (WEF) prior to its meeting in Davos in January 2008 was reported on Danmark Radio's Text-TV. According to the DR's own wording it read, 'Danes are the most Islam-critical. 79\% of the Danes look at greater interaction with the Muslim world as a threat. In Spain, Holland, Italy and Sweden this share is between 65 and $67 \%$ '.

\section{Identity, belonging and social interaction}

In the questionnaires, respondents were asked to identify the five things they felt said something important about them when describing themselves to others. For both Muslims (80\%) and non-Muslims (50\%) family emerged as the most important aspect of identity. The two groups differed significantly on the importance of religion in their identity. Almost one fifth of the Muslim respondents (18\%) identified religion as important to their identity compared with $2 \%$ of non-Muslims. Thus among Muslims religion is viewed as the second most important aspect of their identity after the family in describing themselves to others. A striking result is that not many from the various ethno-national groups of Muslims regarded their ethnicity, culture or national origin as that important, at least not in the context of defining their self-identity. Also identity through work or profession scored low among them.

Over $40 \%$ of non-Muslims indicated that they did not believe in any religion. However, contrary to the popular myth that Muslims give too much importance to their religion, the survey data demonstrated that for almost $80 \%$ of them religion was not the most

\footnotetext{
${ }^{1}$ Danmark Radio, 21 January 2008. Such international surveys are hardly reported, or debated, in the mass media. Note also the strategy of mitigation in the expression "Islam-critical". Expressions such as islamophobe, Islamophobia, anti-Muslim or anti-Islam are not used any more in the media language.
} 
important marker of their identity in their day-to-day life. ${ }^{2}$ Another such indicator can be read through the response to a question for which the respondents, both Muslim and non-Muslim, were asked to indicate where they encountered people from ethnic and cultural backgrounds other than their own. Not many Muslims reported such encounters at prayer houses or mosques. However, the 'don't know' category for both Muslims and non-Muslims remained high. This is obviously due to the fact that not many respondents visited churches, mosques or other places of worship on sufficiently regular basis to recall an accurate response to the question.

Regarding daily interaction across the ethnic groups, $75 \%$ of Muslims and $45 \%$ of nonMuslims reported work, schools or colleges, and even a higher percentage from both the groups indicated shops and markets, as the prime locations of frequent encounters with people from various cultural and ethnic backgrounds.

Among other variables hypothesized to be of importance, three possible indicators to measure levels of social cohesion are; levels of trust of people in the neighbourhood, whether the residents of the city or a residential area believe that people in their neighbourhood are willing to help their neighbours, and whether they think people in their area share the same values. Only $10 \%$ of Muslims and 5\% of non-Muslims categorically denied that people in the neighbourhood could be trusted. The rest from both the groups responded positively to the question, though the percentage of nonMuslims responding positively was slightly higher. This difference is probably due to the fact that vast majority among the non-Muslims were ethnic Danes, some of whom had resided in the area for much longer, and across generations, compared with the Muslim immigrants. They thus have wider social networks in the local neighbourhoods that provide a sense of ontological security. The language barrier could be another main factor, as not all among the Muslims speak the same language, nor do all of them have

\footnotetext{
${ }^{2}$ Less than c. $17-18 \%$ of Muslims in Denmark go to a mosque for Friday prayers (see, Kühle 2007; Mikkelsen 2008). An international survey (Pew 2008) resonates with the results that about $80 \%$ of Muslims globally do not practise their faith literally or its prescribed rituals, such as five prayers a day.
} 
proficiency in Danish. However, the percentage of responses indicating mutual trust in the sub-district of Nørrebro turned out to be higher than the average in all the European cities surveyed by the project. ${ }^{3}$

On the question of whether they agreed or disagreed that people living in their residential quarter were helpful neighbours, over $80 \%$ agreed, or strongly agreed, in the affirmative: a sign of a good deal of social cohesion and solidarity. But it is the third dimension of shared values that demonstrates the most notable difference in responses. More non-Muslims (59\%) had the view that people living in their area did not share the same values than did Muslims (41\%), whilst about 13 per cent from both groups had no opinion. ${ }^{4}$ These responses can be viewed against the national debate in Denmark-as in other EU countries - for the past decade or so that has been replete with 'our values' (Danish, Christian, Western) versus 'their values' (Muslim, Islamic, Arabic etc.). This rhetoric is not confined merely to the outspokenly anti-immigrant and anti-Muslim Danish People's Party, but is discernible in contributions to political debates on integration by mainstream parties and the media. This value debate has apparently had an impact on responses to the question for both groups, where the Muslim respondents may be more on the defensive to the issue of value differences. Without being patronizing, however, it is also plausible that many respondents from the Muslim groups, among whom the literacy rate is lower than the non-Muslim group, are unable to reflect on this complex issue.

Despite this gap between the two groups on perception of common values, the overall impression from the survey results indicates that there is a greater sense of reciprocal acceptability between Muslims and non-Muslims than there is a social distance of any significance. Against the backdrop of the popular perception of 'ghettos' and 'ethnic enclaves' that has dominated the political and media discourses, about $69 \%$ of Muslims

\footnotetext{
${ }^{3}$ For detailed comparisons, see further, OSI (2009).

${ }^{4}$ The average for all the cities for the non-Muslims who did not believe that people share the same values in their neighbourhood was $55.2 \%$, and $49.9 \%$ for the Muslims.
} 
and $78 \%$ of non-Muslims agreed that people from different backgrounds in their local area get along well with each other.

Both Muslim and non-Muslim respondents identified similar barriers to people getting on well with each other in their neighbourhoods. A lack of cultural understanding was identified as the main barrier. Lack of language skills and prejudice and discrimination were also pointed out as important obstacles. Surprisingly, more non-Muslim respondents pointed at discrimination and prejudice against ethnic minorities as an obstacle towards meaningful social interaction (19\%) than did Muslims themselves $(12 \%)$.

One interesting result of the survey is that few respondents identified crime or violence as a causal factor, despite the fact that during the period of monitoring for this survey Nørrebro had witnessed some of the most dramatic events of violent confrontations between the police and the minority ethnic youth and sporadic but recurrent shootings between Danish rockers and criminal gangs dominated by some minority ethnic youth.

The research reveals that both Muslims and non-Muslims have a strong sense of belonging to their local area. About $80 \%$ of both the groups have a 'very' or 'fairly' strong sense of belonging to their local area. Results of belonging to the city of Copenhagen are also positive, $81 \%$ and $86 \%$ respectively.

Another important aspect of identity and belonging can be viewed by asking not only about how the respondents looked at themselves, but also how they would like to be viewed by the surrounding society. Among Muslims, 38\% said that they considered themselves Danish and 58\% that they did not. The response of non-Muslims was obviously higher; $88 \%$ of respondents said they saw themselves as Danish. While $38 \%$ of Muslim respondents viewed themselves as Danish, and a majority of Muslims 
respondents (51\%) wanted to be seen as Danish, only 14\% felt that other people regard them as Danish.

Both Muslims and non-Muslims mentioned the lack of proficiency in the Danish language as the main obstacle to being seen as Danish. Being a non-white minority member was given as the second significant reason by Muslim respondents. Other research indicates that fair-skinned Bosnian Muslims complain far less about discrimination than Muslim groups such as Somalis, Turks and Arabs. ${ }^{6}$

The questionnaire data suggests that the most frequent interaction across the ethnic boundaries takes place at workplaces and educational institutions, followed by shopping malls and stores. To be more specific on interfaith relations and social encounters, the respondents were asked how often they had met and talked with people from a different religious background than their own in the past year. Among Muslim respondents, $72 \%$ said that they had such contacts on a daily or weekly basis, whilst $53 \%$ of non-Muslim respondents said they had such contacts at various places on a weekly or daily basis. However, one way to look at how meaningful such social contacts across faith and cultural backgrounds are is to ascertain whether people socialize privately with each other. The table below summarizes the frequencies of meetings in private homes across religious backgrounds.

\begin{tabular}{|l|l|l|l|}
\hline Response & Muslim & $\begin{array}{l}\text { Non- } \\
\text { Muslim }\end{array}$ & Total \\
\hline Daily & 15 & 14 & $\mathbf{2 9}$ \\
\hline At least once a week & 13 & 18 & $\mathbf{3 1}$ \\
\hline At least once a month & 16 & 20 & $\mathbf{3 6}$ \\
\hline
\end{tabular}

\footnotetext{
${ }^{5}$ It should be noted that a good number of the respondents are naturalized Danish citizens (52\%) and some of them were born and educated in Denmark.

${ }^{6}$ This observation is based on a range of periodic telephone surveys by Catinét, Copenhagen - a private firm - and also by Møller and Togeby (1999).
} 


\begin{tabular}{|l|l|l|l|}
\hline At least once a year & 20 & 9 & $\mathbf{2 9}$ \\
\hline Not at all & 2 & 3 & $\mathbf{5}$ \\
\hline Don't know & 33 & 35 & $\mathbf{6 8}$ \\
\hline No response & 1 & 1 & $\mathbf{2}$ \\
\hline Total & $\mathbf{1 0 0}$ & $\mathbf{1 0 0}$ & $\mathbf{2 0 0}$ \\
\hline
\end{tabular}

Table 1. How often do you meet with people of other faiths at home?

Source: Open Society Institute (OSI 2008)

If the category 'don't know' is excluded, it is clear from the table that about two-thirds of respondents get together socially at their private homes with people from other faiths or religions on various occasions. A tentative conclusion, supported also by the suggestion given by the respondents themselves when asked what prevents people from different background getting along with each other, could be that it is not religion per se, but often the language barrier, common interests and social standing which may hamper social interaction across ethnic identities in the neighbourhood.

\section{Education}

Education, especially in public schools, is one of the most important pillars of integration. The education system provides individuals with the skills and qualifications for participation in the labour market. It also plays a formative role in the socialization of young people in the unspoken rules and values of society. ${ }^{7}$ Schools also contribute to integration by providing opportunities for interaction between pupils and parents of different ethnic and religious backgrounds. Schools, alongside workplaces and shopping malls, are a key location for encounters between people of different backgrounds. However, such encounters become less frequent, both for parents and children, when schools become segregated on ethnic lines. The Copenhagen city council acknowledges the problem that many native Danes in the city, including Nørrebro, move their children

\footnotetext{
${ }^{7}$ See, for instance, Schiffauer 2001.
} 
to private schools to avoid too many 'bilingual' pupils (those of other ethnic origins) in the public schools.

The tendency of moving children to private schools ${ }^{8}$ is not confined to native Danish parents only. Many Muslim parents who can afford it enrol their children either in ethno-national schools or in international schools with English as their medium of instruction ${ }^{9}$ that are situated outside the vicinity of Nørrebro. As a result many public schools in Nørrebro and in the surrounding areas are dominated by pupils from lowincome groups and families with limited social and cultural capital. The majority of these are from Muslim families. This state of affairs reproduces a vicious circle of marginalization and failure in further education and skills for the labour market, because the drop-out rate remains higher for these children:

The unsatisfactory results in primary and lower-secondary schools contribute to a high drop-out rate among ethnic minorities on further education programmes. When leaving school, the majority of all youngsters-95 per cent - start study programmes or courses to qualify them for the labour market, but approximately 20 per cent drop out each year. The drop-out rate is notably highest on vocational training courses, where up to half of the students drop out. ${ }^{10}$

According to a study by Dahl and Jacobsen (2005), the low performance and higher drop-out among the minority children can be explained by at least five different factors:

\footnotetext{
${ }^{8}$ In the city of Copenhagen as a whole $25 \%$ of pupils were enrolled in private schools in 2007 , whilst the average for the country as a whole was merely 13\% (Statusrapport, 2008 by Dept. of Employment and Integration. City Council, Copenhagen).

${ }^{9}$ In the inner Nørrebro sub-district there are five municipal schools and five private schools; Norrebro Lille Skole, ISRA and DIA, two Muslim schools, the Free Gymnasium and a Catholic school, Sankt Ankar skole.

${ }^{10}$ Integration Policy (2007: 20), Copenhagen Municipality.
} 
1. Lack of proficiency in Danish and poor qualifications from primary schools

2. Negative social inheritance (poor resources in the family) and thus lack of knowledge about the Danish educational system.

3. Lack of 'ethnic capital' (lack of knowledge of Danish culture and society).

4. Ethnic prejudice and discrimination (for example, bullying in schools and playgrounds)

5. A limited network beyond one's own ethno-national background.

A study by the Rockwool Foundation indicates some improvement in the educational trends of minority pupils, but drop-out rates, especially in vocational training colleges, remain higher than for natives at the national level (Jensen \& Rasmussen 2008), though a much more recent media report has noted that due to intensive efforts by the municipality of Copenhagen, native Danish parents have shown a greater tendency to choose the nearest public school for their children than was the case in the previous years. ${ }^{11}$ Copenhagen Municipality's Integration Policy Document ${ }^{12}$ refers to the PISA Survey 2004 and states that there is a constant performance gap between monolingual (with Danish as mother-tongue) pupils and bilingual pupils. The performance gap is attributed to socio-economic differentials and lesser resources among the parents to help children with homework. The Integration Policy aims to narrow the gap in performance between these two groups.

In the OSI survey, education services provided by the municipality emerged as the service that both Muslim and non-Muslim respondents were least satisfied with, after rubbish collection. The survey results reveal that $54 \%$ of Muslims and $22 \%$ of nonMuslims were highly or fairly satisfied with the primary schools, while the rate of satisfaction was $48 \%$ and $24 \%$ respectively for the higher secondary schools and vocational colleges in the area. Eleven out of 65 Muslim respondents and 16 out of 87 non-Muslims expressed dissatisfaction with the municipal schools for poor standards

\footnotetext{
${ }^{11}$ Berlingske Tidende 4 March 2010.

${ }^{12}$ Integration Policy 2007.
} 
and performance. some . 56\% of Muslims and $49 \%$ of non-Muslims reported that the public schools respected the religious customs of their pupils: the average reported for all the cities surveyed is 51.8 and $57.4 \%$, respectively.

Discussion of public schools in the focus group sessions for Muslim women highlighted one salient issue, that Danish parents avoid sending their children to the schools in the local area if they find 'too many' pupils with minority backgrounds in the school. Other topics that became part of the discussions included swimming classes, diet, the right to take a day off school on a Muslim holiday, and teachers' concerns that fasting by small children during Ramadan hampered their concentration in the classroom. The following exchange in one focus group session indicates some of the parents' concerns:

(Voice A) The main problem is that when the kids have to go swimming, the Danish kids take off their clothes in front of everyone and swim but our kids cannot do that. I tell my kids, such as to my daughter, 'You cannot take off your clothes in front of others; don't say it's me who told you this but say that you yourself don't like to show your naked body to others'.

(Voice B) I know about the school where her daughter goes and my kids have been ... that they have separate arrangements for boys and girls. They know that Muslim girls will not shower in front of boys and so they have separate bathrooms for girls; each girl showers separately and comes out after dressing up. They have separated it all for boys and girls.

(Voice C) It is so in many Copenhagen schools but it is possible that this may not be the case outside Copenhagen; it is done where the majority of pupils are Muslim.

Generally, though, the discussants seemed to be satisfied with the ways in which these issues were being handled by the school authorities. It should also be mentioned here 
that there is no particular dress code for Danish public schools, and as such there is no restriction on Muslim girls wearing the hijab. ${ }^{13}$

Criticism of state-run public schools came to the surface also during the focus group session on education and employment. One of the participants, who himself had been pupil in a public school, said that atmosphere for the Muslim pupils was not pleasant and that private schools had a better standard of education and space for recognition of the Muslim identity:

Regrettably the public schools in Copenhagen are not performing well... I can recall, when I came to Denmark, how much you had to fight against, when you were in a public school. And it is also frustrating, when you are young and you are finding out who you are, that you are also up against racism and prejudice and other problems... The international schools have no such problems.

The Copenhagen City Council has a range of projects running to improve the situation in the public schools, ${ }^{14}$ but according to an educational consultant at the municipality, their failure or success depends very much on the attitudes of the teachers and the management at the specific schools. According to the consultant, an overarching problem is that due to a general perception in society about immigrants from less developed countries, many teachers entertain low expectations of the children of these migrant families, which has a negative impact on the children's self-esteem. Children from some vulnerable families either drop out of school or become involved in antisocial activities in reaction to non-recognition. The consultant interviewed for the

\footnotetext{
${ }^{13}$ Headgear. Muslim scholars differ on whether hijab in the Koran refers to an attitude of modesty or a piece of cloth.

14 The details and the nature of these projects are available on the City of Copenhagen website at http://www.kk.dk/integration (accessed October 2009).
} 
survey stressed a need for reforms and structural changes in the school such as training staff in multicultural pedagogy. ${ }^{15}$

\section{Employment}

Until the 2008 crisis in the international finance markets, Denmark enjoyed one of the highest rates of employment among the EU countries. Some sectors of the economy were suffering acute shortage of labour to the extent that immigration rules for skilled labour and expertise had to be relaxed to meet the increasing demand for professionals in particular industries and service sectors. The upswing in the economy prior to the recent recession also helped the minority ethnic communities whose unemployment rate had been much higher than the native Danes for many years. In Copenhagen, $74 \%$ of working-age people of Danish origin (men and women combined) were employed in 2005, but the figure for immigrants from non-Western countries was far below, at $47 \%$. The picture was more dismal for minority women. While $74 \%$ of native Danish women worked, the figure for non-Western women in the city was just under $41 \%{ }^{16}$ The Copenhagen City Council suggests two explanations for the lower employment rate for immigrants:

One is that there is a very large group of immigrants that has absolutely no contact with the labour market: More than one in three immigrants of employment age is outside the labour market, while the figure for Danes is just under one in five. The second explanation is that immigrants who are actually on the labour market are more likely than Danes to be unemployed. The unemployment rate in Copenhagen is approximately 6 per cent for Danes, compared with 19 per cent for immigrants. In addition to this, immigrants

\footnotetext{
${ }^{15}$ Interview with Assad Ahmed (Copenhagen, 21 August 2009). A survey by Bo Ertman from the Centre for Theory and Method Research reported that $70 \%$ of those migrant youth who are involved in petty street-crimes hail from vulnerable refugee families suffering from traumas of wars and violence. DR Text-TV, 27 December 2008.

${ }^{16}$ Integration Policy 2007.
} 
typically work in specific industries in which pay is often lower, job security poorer and skill enhancement opportunities fewer, compared to other industries. $^{17}$

The situation for the self-employed in Copenhagen is no less precarious, as many Muslims living in the city make their living through kiosk-shops, grocery stores, and driving taxis. According to the City Council, 30\% of new businesses launched by entrepreneurs with an immigrant background close within their first year, compared with $20 \%$ of new businesses launched by entrepreneurs with a native Danish background.

Among respondents in the OSI survey, 28\% of Muslims and 34\% of non-Muslims were, at the time of the survey (2008), in full-time employment, while a further $14 \%$ of both groups were in part-time employment. A greater proportion of Muslim respondents (14\%) than non-Muslim respondents were self-employed. A greater proportion of Muslim respondents (10\%) than non-Muslim respondents $(6 \%)$ were unemployed and looking for work. Muslim respondents (10\%) were also more likely than the nonMuslims (2\%) to be out of the labour market due to sickness or disability.

A starker contrast between the labour market participation of Muslim and non-Muslim respondents emerges when account is taken of the types of jobs people take. Among the Muslim respondents in employment, the largest number was found in routine manual or service occupations followed by semi-routine manual and service occupations. By contrast, the largest group of non-Muslim respondents were in modern professional occupations and clerical or intermediate occupations.

Over the last decade or so the network theory has gained increasing importance in explaining differences in labour market participation. Most vacancies, especially in routine manual work and semi-routine manual work in services and manufacturing, are

\footnotetext{
${ }^{17}$ Ibid., p. 12.
} 
filled through network relations. Very often employers make sure that they can trust a new employee through personal references by those who are already in the firm. At the same time many job-seekers obtain information about employment opportunities through their personal networks of friends and family. This state of affairs can put migrants in a disadvantageous position such that they end up finding the same type of jobs which their close networks are already engaged with: dead-end jobs, low-paid and in an ethnic niche. ${ }^{18}$

Respondents to the OSI Survey were asked how they obtained their jobs. It was obvious from the responses that the largest proportion of the employed, both Muslims and the non-Muslims, relied on network relations followed by personal initiatives of contacting the potential employers. A negligible number of the employed got their jobs through municipal job centres. ${ }^{19}$ The importance of networks beyond one's own ethnic community was also emphasized in the focus group on education and employment: there was general feeling that immigrants generally lack network- relations beyond their own ethno-national groups or communities.

A well-educated female participant in the group observed that she had not personally faced discrimination in the employment market, but she acknowledged that discrimination was a problem. This was exemplified by the high demand for labour in the health sector, which meant that many Muslim girls would like to learn and work in the sector, but the national hijab debate and signals of distance to Muslim staff wearing head-scarves in hospitals inhibits their motivation. On the other hand, she was not in favour of solving the problem of prejudice and discrimination in the private labour market through legislative sanctions.

\footnotetext{
${ }^{18}$ In his 1999 book, Durable Inequalities, touching upon Italian immigrants in New York, sociologist Charles Tilly, however, holds that the network ties do produce general inequalities in the labour market but are also a source of protection, especially for new arrivals of immigrants.

${ }^{19}$ Their inefficiency has often been criticized in a range of reports in the media..
} 
A quantitative survey conducted on behalf of the Danish Federation of Labour Organizations (LO) on attitudes among Danes towards Muslim colleagues at workplaces suggests that there is a good deal of scepticism about Muslims despite the personal experience of working with them. The survey indicates that one third of nonMuslims are of the view that Muslim women should not be allowed to wear the hijab at the workplace, and a majority think that Muslims should not be allowed to perform the ritual prayer in working hours. Almost half of the respondents wished not to be confronted with the religious practices of their colleagues at their workplace. The vast majority believed that Muslims were creating problems by making demands for special treatment because of their religion. However, the survey also revealed that the majority of respondents had no objection to their Muslim colleague's right to halal food and that they should have the right to time off on their crucial holy days (i.e. Eid). ${ }^{20}$

\section{Health, Social Care and Welfare}

A few social science studies concerning health were performed during the 1980s, mainly of an anthropological nature, focusing on traditional Muslim cultures and covering topics such as the traditional Muslim culture's encounter with modern Danish hospitals, superstitious belief systems about illness and health among Muslims, the use of amulets among immigrants against the 'evil eye', the concepts of 'hot' and 'cold' food and beverages, believed to influence the body, and so on. ${ }^{21}$ Today, the focus has turned more to the real-life health problems prevalent among Muslim immigrants and their descendants, covering topics such as complications during birth and pregnancy, and frequently diagnosed diseases among immigrant communities such as diabetes, cardiovascular problems, health hazards due to diet and lifestyle, and so on. A good deal of medical research is already in progress at various medical faculties and research institutes across the country.

\footnotetext{
${ }^{20}$ Ugebrev A4, no. 200913.

${ }^{21}$ See, for example, Elverdam (1991) and bibliographical references there.
} 
One such study provides evidence of the positive effects of having female health visitors for mothers from minority communities. According to this study, female health visitors provide a bridge to the surrounding society and its institutions for many migrant families; they are a source for information about matters such as how to secure a place in a nursery or apply for a better dwelling after the extension of the family (Jeppesen \& Nielsen 1998). Nielsen (2002) finds that other benefits also arise from having female health visitors, including ensuring the timely vaccination of babies and a reduced level of hospitalization The health visitors thus not only provide a good deal of useful information about how to solve various problems falling outside of the health sector, but also timely guidance to safeguard against health risks, which reduces the frequency of visits to physicians and hospitalization. The difficulties of communication that arise from the lack of fluency in Danish among some first-generation migrants are a problem identified by Nielsen (2002). Language barriers and communication problems make it difficult to diagnose and treat patients. ${ }^{22}$ Nielsen recommends provision of qualified interpreters by the municipal social services and hospitals, as this can reduce the levels of unnecessary hospitalization of minority patients.

The frequency of psychological problems is reported to be high among members of ethnic minorities. This is partly explained by the fact that a large section of the population has fled wars and torture. Singla (2004) analysed psychosocial strains experienced by minority youth due to intergenerational gaps with their parents, and their own identity struggle in a discriminatory environment. Skytte (2002b) explored the various aspects of traumas and tragedies faced by children and their parents from foreign (including Muslim) cultures when municipal social authorities take children away from troubled families and place them in the custody of Danish families. She also explored the situation of the most vulnerable sections of the minority ethnic communities, such as the elderly in need of social protection and care (Skytte 2002a).

\footnotetext{
${ }^{22}$ The language barrier has been noted by other scholars as well. See on this, for instance, Skytte, 2002a; Barfod \& Leimand, 1996; Barfod, 1997; Barfod \& Persson, 2000.
} 
In the OSI survey, respondents were asked to express their opinion on a range of municipal social services. For the health services in general the vast majority from both the samples, Muslims and non-Muslims, expressed great satisfaction. The Muslim respondents who were not satisfied (18\%) had their main concern with lack of interpretation facilities during visits to their doctors or hospitals. Some provided anecdotal examples of using children as the interpreters for their parents.

Health was also an issue that was brought forth in discussions in several sessions of focus groups. Talking about why members of ethnic minorities were found to be more prone to diabetes and heart diseases and whether it was linked to lack of information, a respondent from one focus group had the view that

There are so many good programmes about health, doctors give talks, but the majority of our people do not understand them. That is why the general information disseminated by the Department of Health does not reach our people. I will give you a small example. About a year and half ago, there was a women's group in ... which provided information about health, particularly diabetes, and the women asked that if two persons were eating from the same plate and one had diabetes, would the other catch the disease? This shows the extent of lack of knowledge among our people... There is a severe lack of knowledge and information.

Lack of proficiency in Danish and thus lack of exposure to the daily news media became a focus of discussion in several sessions, and the participants were of the view that this creates problems not only in the health sector but in many areas of daily life such as adequate information on rules and regulations about retirement and pensions, educational institutions and the provision of social services. However, the overall impression about the healthcare provision in the municipality was positive-worries about the old-age care notwithstanding - in all the sessions in which issues of healthcare became the focus of talk. 
As far as social protection is concerned, complaints of dissatisfaction with the social services in the survey were rare. An interview with the administrative head of the Women's Centre for Immigrant Women in Nørrebro, however, provides a glimpse of the problems for which the immigrant women visit this centre, partly financed by the municipality and partly financed by private donations. The head of the centre noted that, in addition to those regular visitors at the centre for pastimes, hobbies and chat with like-minded women, the centre was used by an average of 250 women per year for counselling on a range of social problems. These included domestic conflicts, psychological problems, poverty and economic issues, troubles with social authorities if living on social welfare benefits, advice about children and so on. ${ }^{23}$

\section{Citizenship, political and civic participation}

Seen from the formal legal perspectives, Muslim immigrants in Denmark enjoy all those universal rights on civic and social dimensions and political and economic citizenship that are considered vital for a vibrant democracy in a modern welfare state. Although there is no restriction on practising any faith or religion, it is the exercise of cultural citizenship that has been one of the core issues on the agenda, ever since the labour migrants of the 1960s began to organize themselves on political, national or cultural platforms in the mid-1970s (Hussain, 2002; Mikkelsen, 2002; 2003).

In the OSI survey, $52 \%$ of Muslim and $83 \%$ of non-Muslim respondents said that they were eligible to vote in national elections. Two things are to be noted here regarding participation in the formal democratic processes. First, that almost half of the Muslims, at the time of the survey, did not have voting rights for the national parliament, because only Danish citizens are eligible to vote. And out of the 52 Muslim respondents who had Danish citizenship, ten did not cast their vote, whereas only four out of the 83 eligible non-Muslims respondents did not vote in the last national election. When the data for voting at local elections is examined, we see that only 18 respondents from the Muslim group and 8 non-Muslims said they did not have the voting rights for local and

\footnotetext{
${ }^{23}$ Interview with Margrethe Wivel, Women Centre for Immigrant Women, Nørrebro (14.09.2009).
} 
regional councils, yet proportionally more Muslims than non-Muslims abstained from using their voting rights. Nonetheless, $74 \%$ of Muslims voted in the last local elections, while $87 \%$ of non-Muslims took part in the elections.

The propensity to participate in political processes, including motivation to vote, increases under normal circumstances if people believe that their vote can bring a change for the better for themselves. The OSI survey shows that the majority of both Muslims and non-Muslims had little trust in the national government. Regarding local government there was far greater trust among Muslims, who are more likely than nonMuslims to say they have 'a lot' of trust in local government.

At the national level, $61 \%$ of Muslims but only 34\% of non-Muslims believed that they had no influence on political decision-making. In comparison, 56\% of Muslims and only $28 \%$ of non-Muslims held the view that they had no influence on decisions affecting their city, despite the fact that during the survey period there were five elected minority members serving on the City Council, of whom at least four can be said to have a Muslim background. Although the sample frame from Nørrebro is not strictly a representative sample in the statistical terms, the results showing the relatively lower political motivation among the Muslim residents in Nørrebro correspond to the results of national surveys (see further, Mikkelsen 2008).

Respondents were also asked whether they had taken part in consultation or public meetings about local services or problems in their local area in the last 12 months: 26 respondents $(n=100)$ from the non-Muslim sample and 21 from the Muslim sample $(\mathrm{n}=100)$ answered in the affirmative to this question. Among those who had been active, many took part in the elections of their local associations of residents or tenants, and in local initiatives for better integration in their residential quarter or neighbourhood.

In the special focus group for discussions on policing and civil and political participation conducted among the relatively well educated and professionals, a range of topics concerning political participation was brought onto the agenda. These included 
general apathy among Muslim citizens, a lack of social and cultural capital among Muslim politicians, lack of cooperation between the elected politicians from ethnic minorities in the city council, and the negative attitude towards the minority associations and organisations in the mass media. A female participant spoke about participation in the democratic process:

I always feel that being a Muslim one has to do [a good deal of] extra work just to be recognised for what one stands for. [Already] in school it is not enough that you are brilliant but you have to prove that you are the best before you are recognized on equal footings like your classmates. So I do not feel that it is so [that you have the same opportunities].

Another participant mentioned the general suspicion about the Muslims in the country;

One thing is to have the possibilities and rights to take part in the societal processes. But it is quite another thing, how you are treated as a citizen. This can be the case in the local areas but it is also a broader case. And with the latest measures which we are witnessing at the moment, we are reaching the [former East German] DDR situation. And with that I mean that we have begun to talk about how school-teachers, managers and coaches in sports clubs, and scout-leaders shall keep eye on [Muslim youth] to monitor increasing radicalization among the youth without ever bothering to define what radicalization is all about.

Visible signs of being a Muslim, like wearing a hijab, were discussed with reference to a Danish debate on whether a Muslim woman wearing a headscarf can be a member of jury or a judge, ${ }^{24}$ and whether she be allowed to speak from the podium of Danish parliament. One participant held the view that showing any sign of religiosity by

\footnotetext{
${ }^{24}$ This national debate ended with the Danish parliament passing a bill prohibiting any judge or a jury member from entering a court while wearing religious clothing or symbols.
} 
politicians renders them less objective in the public eye: 'So if you are not religious, you will be considered the most neutral, but if you have religion, be it Islam, Christianity or any other religion, also Judaism, so we are not taken as neutral'. No one disagreed.

\section{Conclusion}

Integration of Muslims in Denmark has been on the political and media agenda for several years, and this is the only faith community among all the immigrant communities whose integration into society is problematized on a regular basis in public debates. The survey which this article reports had focused on Muslim integration at the city level on the assumption that social cohesion and reciprocal integration at a societal level always begin in the local residential areas and neighbourhoods through interaction with the institutions and the resident population of the area.

The OSI survey results reveal that, in contrast to a negative perception of Muslims and to anti-Islam attitudes at the national level, the city council of Copenhagen has taken a pragmatic approach in its effort to integrate its Muslim citizens. Muslim respondents expressed a greater trust in the local government than in the national government, and their sense of belonging to their local residential areas and the city was significantly higher than their sense of belonging to the society at large.

For the standard questionnaire, a control group of 100 self-defined non-Muslims in the sub-district were also interviewed to analyse whether the Muslim identity affected their perceptions of social relations and opinions about city policies, provision of the welfare services, and inter-ethnic relations across the ethno-national boundaries. This demonstrated that, contrary to popular rhetoric about some urban areas turning into 'parallel societies' and secluded ghettos, there are signs of a good deal of meaningful social interaction between the minorities and the majority living in the district. However, the factors that may prevent meaningful social encounters between various ethnic or faith groups or individuals are reported to be; lack of language proficiency, a 
lack of cross-cultural understanding, and different interests based on socio-economic position and professions, not the religious identity per se.

The overall results from the survey suggest that, despite some neighbourhoods in the area surveyed having an overwhelming multi-ethnic composition and an excess of socially and economically vulnerable citizens, there are no signs of seclusion of the Muslim communities from the rest of the surrounding society, or of the development of a parallel society. People belonging to various faith communities have frequent interaction with each other in both formal and informal sites and arenas. The vast majority (more than $80 \%$ ) of both the groups were quite satisfied with living in their respective residential quarters and were getting along well with each other and expressed a strong sense of belonging to their local area and the city. Contrary to media images of Nørrebro as a conflict-ridden area of crime and youth deviancy, residents felt themselves secure and safe in their neighbourhoods. All such indicators point towards social cohesion and integration.

\section{References}

Andreassen, R. 2005: “The Mass Media's Construction of Gender, Race, Sexuality and Nationality. An Analysis of the Danish News Media's Communication about Visible Minorities from 1971-2004”. PhD dissertation, Department of History, University of Toronto.

Barfod, A. 1997: Integration, rummelighed og tolerance. Faglig netvark socialpsykiatri. (Integration, spaciousness and tolerance. Professional network of social psychiatry). Social Development Centre (SUS), Copenhagen.

Barfod, A., and O. Leimand 1996: Sindslidende indvandrere og flygtninge (Immigrants and refugees with mental illness). Social Development Centre (SUS), Copenhagen. 
Barfod, A. and L. Persson 2000: Etniske sindslidelse i kommunerne (Mental illness among ethnic minorities across the municipalities). Social Development Centre (SUS), Copenhagen.

Catinét Research 2005: IntegrationStatus (2004; 2005) 1.halvår (Integration Status 2004 \& 2005: First half-year reports). Catinét Research, Copenhagen.

CERD. 2002: "Consideration of Reports Submitted by States Parties under Article 9 of the Convention. Concluding observations of the Committee on the Elimination of Racial Discrimination, Denmark", United Nations Standing Committee on the Elimination of Racial Discrimination (CERD), Geneva, CERD/C/60/CO/5, 21 May 2002. Available at http://www.unhcr.org/refworld/publisher,CERD,,DNK,3d5a73c423,0.html (accessed 1 July 2010).

Dahl, K. M., and V. Jacobsen 2005: Kфn, etnicitet og barrierer for integration. Fokus på uddannelse,arbejde og familieliv (Gender, ethnicity and barriers for integration. Focus on education, work and family-life). The Danish National Institute for Welfare Research (SFI), Copenhagen.

ECRI 2000: The 2nd Country Report on Denmark. Strasburg: the European Commission on Racism and Intolerance (ECRI), Council of Europe, adopted 16 June 2000. Available at: http://hudoc.ecri.coe.int/XMLEcri/ENGLISH/Cycle_02/02_CbC_eng/02-cbcdenmark-eng.pdf (accessed 1 July 2010).

EUMC 2002: Islamophobia in the EU after 11 September 2001. May 2002. European Monitoring Centre on Racism and Intolerance (EUMC), Vienna. Available at: http://fra.europa.eu/fraWebsite/attachments/Synthesis-report_en.pdf (accessed 1 July 2010).

EU-MIDIS 2009: European Union Minorities and Discrimination Survey, European Fundamental Rights Agency (FRA), Vienna.

Eurobarometer 2008: Eurobarometer 69. Public Opinion in the European Union. European Commission, Brussels, Spring 2008. 
Elklit, J., Møller, B., Svensson, P., and Togeby, L. 2005: Gensyn med sofavaelgerne. Valgdeltagelse i Danmark. Aarhus University Press, Aarhus.

Elverdam, B. 1991: Institutioner og Traditioner. Muslimske Kvinders mфde med danske hospitaler og praksislage. (Institutions and traditions: Encounters between the Muslim women and Danish hospitals and the general practitioners). SHFR and Aarhus University Publishers, Aarhus.

Flachs, L., and K. Meldgaard. 1999: "Tilslutning til børneundersøgelser og vaccinationer - et forsøg på at bedre tilslutningen" (An exercise for securing a better response (from minority parents) for medical check-ups and vaccinations of children). in Månedsskrift for Praktisk Lagegerning (Monthly Newsletter of Medical Practitioners), no. 77, 249-256.

Fraser, N. 2003: Redistribution or Recognition? A Political-Philosophical Exchange. Verso, London.

Græm, C.D. 2003: "Constituting Political Community: The Case of Danish Integration Councils". dissertation, MSc. in Political Science, Department of Sociology, London School of Economics, London.

Hammer, O., and I. Bruun 2000: Etnisk minoriteters indflydelseskanaler (Ethnic minorities' channels of influence). Department of Political Science, Aarhus University, Aarhus.

Hervik, P. 2003: "Det danske fjendebillede" (The Danish image of an enemy) in: Mona Shiekh, Fatih Alev, Baber Baig and Noman Malik (eds): Islam i bevagelse (The dynamics in Islam). Academic Publishers, Copenhagen.

Hervik, P. (ed.) 1999: Den Generende Forskellighed. Danske svar på den stigende multikulturalisme (The annoying diversity: the Danish response to increasing multiculturalism). Hans Reitzels Publishers, Copenhagen.

Hussain, M. 2002: "Etniske minoriteters politiske organisering i Danmark" (Political organization of the ethnic minorities in Denmark). In: F. Mikkelsen (ed): Bevagelser $i$ Demokrati. (Political movements in democracy). Aarhus University Press, Aarhus. 
Hussain, M. 2000: "Islam, Media and Minorities in Denmark" in Current Sociology, 48, 4, special issue on the Muslim family in Europe: 95-116.

Hussain, M., Tim O’Connor and Ferruh Yilmaz 1997: Medierne, minoriteterne og majoriteten - en undersøgelse af nyhedsmedier og den folkelige diskurs (The media, minorities and the majority - an investigation of the news media and of public discourse). The Board for Ethnic Equality, Copenhagen.

Integration Policy 2007: Copenhagen: Secretariat of Employment and Integration, Municipality of Copenhagen.

Jacobson, B. A. 2009: Religion som fremmedhed i dansk politik. En sammenligning af italesattelser af henholdsvis jøder og muslimer i dansk politisk 1903-1945 og 1967-2005. [Religion as foreignness in Danish politics; A comparison of debate on Jews and Muslims in Danish politics 1903-1945 and 1967-2005] Institut for Tværkulturelle og Regionale Studier [Institute of Cross-cultural and Regional Studies], Copenhagen University, Copenhagen.

Jensen, P. and Rasmussen, A.W. 2008: Immigrant and Native Children's Cognitive Outcomes and the Effect of Ethnic Concentration in Danish Schools. The Rockwool Foundation and Southern Danish University Press, Odensen.

Jeppesen, K.J. \& Nielsen, A. 1998: Etniske minoritetsbørn I Danmark - det første leveår (Ethnic minority children in Denmark - the first year of life). Socialforskningsinstituttet, Copenhagen.

Justesen, P. 2003: “International Kritik - Den nationale arrogance" (International criticism - The national arrogance) in: C. Fenger-Grøn, K. Qureshi and T. Seidenfaden (eds): Når du strammer garnet (When you tighten the yarn). Aarhus University Press, Aarhus.

Kehlet, C. 2000. Demokratiske barrierer - Om etnisk minoriteters politisk deltagelse $i$ Danmark (The democratic barriers - political participation of immigrants in Denmark). MA dissertation, Institute of Anthropology, Copenhagen University, Copenhagen.

Kühle, L. 2007: Moskéer i Danmark (Mosques in Denmark). Univers Publishers, Hoejberg. 
Kymlicka, W. 1995: Multicultural citizenship. A liberal theory of minority rights. Clarendon Press, Oxford.

Madsen, G.G. 2000: Mediernes konstruktion af flygtninge og indvandrerspørgsmålet. (The media's construction of the refugees and immigrant issues). Magtudredningen \& Aarhus Universitets forlag, (The Power Inquiry \& Aarhus University Press), Aarhus.

Marshall, T.H. 1950: Citizenship and Social Class. Cambridge University Press, Cambridge.

Mikkelsen, F. 2008: Indvandring og Integration (Immigration and integration). Academic Publishers, Copenhagen.

- 2003: Indvandrere Organisationer i Norden (Immigrant Organisations in the Nordic Countries). Academy for Migration Studies in Denmark (AMID) \& the Council of Nordic Ministers, Aalborg.

- 2002: Indvandrere og civil samfund (Immigrants and civil society). AMID Working Paper Series no. 18, Academy of Migration Studies in Denmark (AMID), Aalborg University. Aalborg.

- 2001: Integrations Paradoks (2001) (The Paradox of integration), Catinét, Copenhagen.

Ministry of Integration, 2006: Udviklingen $i$ udlaendinges integration $i$ det danske samfund. (Integration trends for foreigners in Danish society). Think-tank of the Ministry of Integration, Ministry of Integration. Copenhagen.

Modood, T., A. Triandafyllidou and R. Zapata-Barreo (eds.) 2006: Multiculturalism, Muslims and Citizenship - A European Approach. Routledge, London.

Mouritsen, P. 2006: "The Particular Universalism of a Nordic Civic Nation: Common Values, State Religion and Islam in Danish Political Culture”. In: T. Modood, A. Triandafyllidou and R. Zapata-Barreo (eds). Multiculturalism, Muslims and Citizenship - A European Approach. Routledge, London.

Møller, B., and L. Togeby. 1999: Oplevet Diskrimination (The Experienced Discrimination). The Board for Ethnic Equality, Copenhagen. 
National Focal Point for Denmark.2005: National Annual Report. Copenhagen: Documentary and Advisory Centre on Racial Discrimination (DACoRD), Copenhagen.

National Focal Point for Denmark, 2004: Report on Education. Documentary and Advisory Centre on Racial Discrimination (DACoRD). Copenhagen.

Nielsen, A. 2002: Sundhedsvasnet og de etniske minoriteter (Ethnic minorities and the healthcare system). AMID Working Paper Series no. 28. Aalborg University, Aalborg.

OSI 2009: Muslims in Europe - A Report on Eleven EU Cities. Open Society Institute, Budapest.

Parekh, B. 2005: Rethinking Multiculturalism. Cultural Diversity and Political Theory. Palgrave, Basingstoke.

PET, 2006: Arsberettninger, Politiets Efterettningstjenste (Annual Report of the Police intelligence Service), The Police Intelligence Bureau (PET), Copenhagen.

Pew 2008: The Great Divide. How Westerners and Muslims View Each Other. Pew Global Attitude Surveys, Washington DC.

Singla, R. 2004: Youth Relationships, Ethnicity \& Psychosocial Intervention. Books Plus, New Delhi.

Skytte, M. 2002a: "Anbringelse af etniske minoritetsbørn" (A replacement for social custody of minority ethnic children). PhD dissertation, University of Lund, Lund.

Skytte, M. 2002b: Sociale indsatser $i$ forhold til de allersvageste blandt de etniske minoriteter (Social measures for the most vulnerable among the ethnic minorities). AMID Working Paper Series no. 29, Academy of Migration Studies in Denmark (AMID), Aalborg University, Aalborg.

Statusrapport 2008: (Status Report 2008). Department of Employment and Integration, Copenhagen City Council. Copenhagen.

Schiffauer, Werne 2001: “Staat-Schule Ethnizität” (State-school ethnicity), in: Frank Gesemann, (ed.): Migration and Integration in Berlin [publisher unknown. Here cited through a paper translated into English]. 
Schmidt, G. and V. Jacobsen 2000: 20 år I Danmark. En unders $\phi$ gelse af nydanskeres situation og erfaringer (Twenty years in Denmark: research on the new Danes' situation and experiences). National Institute of Welfare Research (SFI), Copenhagen.

Tilly, C. 1999: Durable Inequalities. University Press of California, San Diego.

Togeby, L. 2005: "Participation in elections". In: Simon, Christiansen and Helle Stenum et al. (eds) Minority Report, first edition. Available at $\mathrm{http} / /$ www.mixeurope.dk

Togeby, L. 2003: Fra fremmedarbejder til etniske minoriteter (From foreign-workers to ethnic minorities). Hans Rietzels Publishers, Copenhagen.

Togeby, L. 2002: Etnisk minoriteters deltagelse I demokratiske processer, herunder politiske partier, valg og offentlig debat (Participation in the democratic processes: ethnic minorities' participation in political parties, elections and the public debate).

AMID Working Paper Series no. 20, Academy of Migration Studies in Denmark (AMID), Aalborg University, Aalborg.

Uni-C Statistik og Analyse 2005: (Uni-C Statistics \& Analysis) Statistiskinformation (Statistical Information). Available at http://www.statistik.uni-c.dk

The complete survey report can be downloaded from www.soros.org/initiatives/home. 